\title{
Production of highly nutritious functional food with the supplementation of wheat flour with lysine
}

\author{
Cs. Albert ${ }^{1}$ \\ e-mail: albertcsilla@cs.sapientia.ro
}

R. V. Salamon ${ }^{1}$

e-mail: salamonrozalia@cs.sapientia.ro

\section{J. Prokisch ${ }^{2}$}

e-mail: jprokisch@agr.unideb.hu

\author{
S. Gombos \\ e-mail: gombossandor@cs.sapientia.ro
}

Z. $\mathrm{Csiki}^{3}$

e-mail: csikizoltan@agr.unideb.hu

$$
\begin{gathered}
\text { J. Csapó }{ }^{1,2} \\
\text { e-mail: csapo.janos@gmail.hu }
\end{gathered}
$$

${ }^{1}$ Sapientia Hungarian University of Transylvania, Faculty of Miercurea Ciuc, Department of Food Science, RO-4100 Miercurea Ciuc, Piata Libertăţii 1., Romania

${ }^{2}$ University of Debrecen, Faculty of Agricultural and Food Sciences and Environmental Management, Institute of Food Technology, HU-4032 Debrecen, Böszörményi út 138., Hungary ${ }^{3}$ University of Debrecen, Medical and Health Centre, HU-4032 Debrecen, Nagyerdei krt. 98., Hungary

\begin{abstract}
During our research, we added 0.5-2.0\% L-lysine to wheat flour in order to increase the quantity of this essential amino acid and the biological value of the wheat protein, producing such a functional, healthprotecting, and health-preserving foodstuff that is suitable for satisfying
\end{abstract}

Keywords and phrases: L-lysine, lysine supplementation, essential amino acid, biological value of protein, Maillard reaction, amino acid analysis, high-performance liquid chromatography 
the lysine requirement of humans, assuming normal nutrition. Furthermore, by the increase of the biological value completing the wheat flour with a higher amount of lysine, we could produce such a functional, health-protecting and health-preserving food that is suitable for containing or preventing lysine malnutrition symptoms. During our work, we determined the quantity of the Maillard reaction products (hydroxymethyl-furfural) and the lysine content developed during the baking of the wheat flour used for bread baking and in the bread baked with supplemented or without supplemented lysine, and evaluated the sensory characteristics of the produced functional food and the bread supplemented with lysine.

\section{Introduction}

Nowadays, there is a growing interest in functional foods with therapeutic effects and an increasing number of articles on the issues of diet and health. Numerous books, periodicals, and online information have been published on the effects of functional foods and several television programmes are focused on the topic of disease prevention and treatment (Wildman, 2007). The functional food industry - consisting of food, beverage, and supplement sectors - is one of the several areas of food industry that has been experiencing fast growth in the recent years. The propelling force of this significant increase does not only consist of the group of health-conscious customers but it also involves certain endemic diseases inseparable from our civilized lifestyle (diabetes, diseases of the nervous and digestive system). These days, many of us are still sceptical about the beneficial effects of functional foods since in order for them to take effect we are required to consume these products on a regular basis, while their beneficial effect might take months or even years to yield the desired outcomes.

In several countries of the developed world, protein deficiency is a prevailing factor due to the predominance of low-protein plant-based diet. Protein deficiency may lead to growth retardation/delayed growth, oedema formation, and anaemia, whereas in case it is combined with energy deficiency the resulting malnutrition may cause death in many infants and young children. As a result of researches carried out in the past decades, today's subject-matter is not the protein needs in general but the specific quantitative requirements in terms of the essential amino acids. It has also been revealed that we must not only cover the deficiencies in limiting amino acids but we must also aim at achieving a balanced ratio of essential amino acids. Moreover, we must also 
pay close attention to obtaining an optimal ratio of essential/non-essential amino acids in our foods.

Once the industry-like production of amino acids has started, green light is given for amino acid supplementation, during which growth will approximate the optimal value. Recently, besides data on amino acid requirements, the optimal and minimal protein levels are also provided. In case of a sufficient protein level, the energy surplus will facilitate the energy-intensive process of protein synthesis, increase weight gain, and enhance benefits and protein utilization (Csapó \& Csapóné, 2007; Csapó et al., 2007).

\section{Literature review}

\subsection{Enhancing the nutritional value of wheat flour and wheat- flour-based products}

The protein needs of an adult person is $80-110 \mathrm{~g} /$ day depending on age and the exerted physical effort. In the case of a mixed diet, this amount of protein contains sufficient essential amino acids, but a one-sided diet may result in essential amino acid deficiency even if combined with an adequate protein consumption. Essential amino acids for an adult person include the following: isoleucine, leucine, lysine, methionine, phenylalanine, histidine, tryptophan, valine, and threonine (Csapó \& Csapóné, 2004). Proteins that contain all essential amino acids in a sufficient amount and in an adequate proportion are called complete proteins - such are the proteins of meat, egg, and milk. Plant-based proteins, however, lack lysine, methionine, threonine, and tryptophan to varying degrees. Since there may occur certain abnormalities in the vital functions of those consuming small amounts of complete proteins, they supplement the largely plant-based foodstuffs with the missing essential amino acids. This supplementation would be most needed in the case of cereal-based foodstuffs because the proteins of wheat and rye contain only small amounts of lysine, methionine, and threonine.

In Europe, people usually tend to opt for a supplementation with natural protein resources, for which the various soy-based products are the most suitable as soy protein contains a large amount of lysine and is stocked up with threonine above the average level. Its disadvantage is, however, the relatively low methionine content. Primarily, they used to fortify wheat-flour-based products - the efficiency of this protein supplementation is examined with the help of biological or chemical verification methods. Chemical methods can provide faster results, allowing us to determine the protein's amino acid 
composition and compare it to complete proteins by the calculation of such chemical indices that give numerical information on the nutritional value of food proteins (Csapó \& Csapóné, 2006).

\subsection{The use of lysine in flour enrichment}

The amount and ratio of amino acids in wheat is far from the optimal values necessary for the human organism, giving the nutritional value of wheat protein a score of approx. 53 on a scale of 100. Since there is a low proportion of lysine first of all, the high-lysine-content materials are the most suitable for the amino acid enrichment of wheat flour (potato (biological value: 73) and soy (biological value: $74-78)$ ).

As the regular consumption of foodstuffs made from cereals is a widely used practice in our days, people have long been engaged in using trace elements ( $\mathrm{Se}, \mathrm{Ca}, \mathrm{Cu}, \mathrm{Zn}, \mathrm{Fe}, \mathrm{P}$ ), vitamins (vitamin B family, vitamin $\mathrm{E}$ ), proteins, and amino acids (tryptophan, lysine, threonine) in flour enrichment and fortification procedures.

Research on the clinical and dietetic application of L-lysine looks back to a history of 30-40 years. In 1976, Titcomb \& Juers patented a type of bread with an amino acid composition corresponding to that of a complete protein. In producing it, besides applying various protein supplementations, L-lysine hydrochloride was added to the flour until reaching a $0.1-0.5 \%$ proportion. Mauron et al. (1976) added to wheat flour the $\varepsilon$-amino acyl derivative of lysine, which will later create lysine during deacylation in the organism. In order to achieve a balanced amino acid composition, aside from acyl-lysine, an approx. $0.1 \%$ of L-lysine hydrochloride was also added to the flour. El-Megged \& Sands (1990) elaborated a procedure during which the lyophilized sample of a lysine-producing lactic acid bacteria strain was added to the leaven, thus enriching the amino acid composition.

On the average, there was a $0.2-0.5 \%$ addition of lysine to the flour in order to increase the protein content. Figueron et al. (2005) added $0.5 \%$ of lysine to the flour, while Muhammad et al. (2012) reported on a $0.2-0.3 \%$ enrichment. Tajammal et al. (2004) employed a $0.5 \%$ enrichment, yielding beneficial effects in children's development, increased haemoglobin level in women, and elevated levels of transferrin in men. According to Karcz (2004), the consumption of $325 \mathrm{~g}$ of bread/day is recommended to satisfy $25 \%$ of people's daily need of lysine.

Wenhua et al. (2004) conducted an experiment where the subjects consumed flour-based bread fortified with $0.3 \%$ of lysine, for a period of 3 months. 
They found that the consumption of lysine-enriched bread has positive effects on the immune system; although the haemoglobin level does not increase, the $0.3 \%$ lysine improves the immune system due to its effect on $\operatorname{IgA}, \operatorname{IgB}$, and $\operatorname{IgE}$.

Several research results confirm the beneficial effects of lysine-enriched flours: Anton et al. (2008) and Mora Aviles et al. (2007) studied the effects of bean meal supplementation in tortilla, Tyagi et al. (2007) investigated the effects of mustard flour in rusk, while Lindenmeier \& Hofmann (2004) looked into how a lysine derivative affects baking properties.

\subsection{The physiological effects of lysine}

It has been known for long that in the absence of L-lysine - the essential amino acid making up our proteins -, dietary calcium cannot get to the bones and the synthesis of a number of proteins will be inhibited. L-lysine plays a fundamental role in the formation of collagen that makes up the organic substance of the bone and skin, but its effect in strengthening the immune system and combatting viruses is also confirmed.

With respect to bone metabolism and the prevention of osteoporosis, the consumption of calcium, phosphorus, and vitamin $\mathrm{D}$ have been for long in the focus of literature as primary nutritional factors although vitamin $\mathrm{C}$ and lysine are also crucial in the formation of collagen making up the organic substance of the bones. Vitamin $\mathrm{C}$ takes part in the activation of vitamin $\mathrm{D}$, on the one hand, and converts lysine, which takes part in building up the collagen substance of the bone, into a form suitable for the creation of procollagen, on the other hand. Research findings corroborate that, besides vitamin C, Llysine is also a major contributor to the formation of a healthy bone structure (Civitelli et al., 1992).

Pauling (1991) reported on the beneficial effects of lysine and vitamin C on the vascular system and on coronary artery diseases. Rath (2001) developed a product suitable for treating diseases related to the impairment of the extracellular matrix (atherosclerosis, cancer, infection, or other inflammatory diseases). The product contained lysine, proline, ascorbate, and their derivatives and synthetic analogues as well as vitamins, provitamins, and trace elements. In their study on L-lysine and the reaction of various carbohydrates, Kitts and $H u$ (2005) demonstrated that Maillard reaction products show a significant antioxidant activity.

In summary, we can state that L-lysine intake in any form increases the biological value of lysine-deficient proteins, contributes to the optimal devel- 
opment of the young organism, and, besides its many therapeutic effects, can be effectively applied in combatting the herpes virus.

\subsection{The role of lysine in the formation of Maillard reaction products}

Monosaccharides, reducing carbohydrates in general, with free amino group, react with each other under appropriate conditions, and by this reaction aroma compounds and brown-coloured pigments, so-termed melanoidins, are created. This process is called the Maillard reaction. In the production of lysine-content bakery goods - as the $\mathcal{\varepsilon}$-amino group of lysine is extremely sensitive to the Maillard reaction -, during the non-enzymatic browning reaction conducted at an appropriate temperature, antioxidants as well as colour and flavour substances are created, which contribute to the health-protective effect (Csapó et al., 2006).

In planning the composition of the ingredients, we must take account of the Lys/Arg ratio and that using any amount of lysine under $1 \%$ should be avoided in order to achieve the desired therapeutic effect, while an amount of lysine exceeding $5 \%$ may significantly spoil the product's palatability traits, as according to our pre-experiments, since the large amount of Maillard reaction products may come with unwanted flavour and colour effects (Csapó \& Csapóné, 2006, 2007).

\section{Aims of the experiments}

The aim of our research is to produce a lysine-fortified bread as a functional food which helps in treating the symptomatic herpes simplex virus and has beneficial effects in the treatment of osteoporosis and other diseases of the circulatory system. We expect that adding a right dosage of lysine - according to our previous researches and preliminary estimates: $0.5-2 \%$ - to wheat flour will increase the amount of essential (and, in the case of wheat flour, limiting) amino acids and that adding an amount higher than necessary for increasing the biological value will result in such a functional, health-protective and health-preserving product that will help eliminate the damages caused by the herpes virus in humans.

We also hope that the compounds produced during the baking of bread, with the remainder of L-lysine, will efficiently inhibit the viral replication of herpes simplex and will have several positive characteristics due to the outstandingly high lysine/arginine ratio, which makes the bread with an enhanced 
lysine content a valuable functional food. As during the baking process breadcrumb temperature does not exceed $100^{\circ} \mathrm{C}$, we were hoping for a practically unchanged lysine content inside the bread, while in the bread-crust and directly underneath of it lysine would be transformed in significant quantities into colour and flavour substances (Maillard reaction) as well as antioxidants.

In summary, the point of our solution is that we make significant changes to the proportion of lysine in relation to the complete amino acid composition, achieving therapeutic effects that will help in curing and preventing herpes besides developing further useful characteristics. Owing to the significant changes in the lysine/arginine ratio, we planned on adding $0.5-2 \%$ of lysine to wheat flour, thus obtaining a functional food of high biological value with health-protecting and health-preserving effects as well. In this article, we report on our research results regarding the lysine-fortified bread, while our future publications will give an account of the production of high-lysine-content biscuit, on investigation into lysine absorption and its anti-herpes effects.

\section{Materials and methods}

\subsection{Combination of the basic ingredients for bread and the baking process}

In planning the composition of the ingredients, we must consider the endproduct's lysine content and its Lys/Arg ratio. Using any amount of lysine under $0.5 \%$ should be avoided in order to achieve the desired therapeutic effect, while an amount of lysine exceeding $2 \%$ may significantly spoil the product's palatability traits, as according to our pre-experiments, since the large amount of Maillard reaction products may come with unwanted flavour and colour effects.

The composition of the raw mixture corresponds with the composition of the similar but lysine-free product. L-lysine was added to the flour in the form of L-lysine-hydrochloride, in a solid, powdery state, and then mixed with the other ingredients and water, in accordance with bread baking technology requirements. To determine the optimal amount of lysine, it was added to the wheat flour in $0.5,1,1.5$, and $2 \%$ concentrations, followed by the examination of all properties of the obtained breads, in compliance with the standard practical procedures used in the qualification of bread.

During the baking of white bread, we complied with the general principles, and made use of the following ingredients: $205 \mathrm{ml}$ water, $20 \mathrm{ml}$ oil, $15 \mathrm{~g}$ salt, $20 \mathrm{~g}$ skimmed-milk powder, $350 \mathrm{~g}$ flour, and $10 \mathrm{~g}$ dry yeast. Depending on the 
nature of the desired product, the dough was leavened, shaped, flavoured, and then baked at $210 \pm 10^{\circ} \mathrm{C}$ in the automatic bread baking machine operated at our Department. With the preliminary results in hand, we can adjust baking temperature and time as required, depending on whether we intend to produce a bread with higher lysine or higher antioxidant content.

\subsection{Analytical investigations}

\subsubsection{Determination of total protein and lysine content}

The total protein content of the obtained breads was determined with the help of Velp Scientifica UDK 159, an apparatus operating on the principle of the Kjedahl method. To measure the amount of lysine, we applied the highperformance liquid chromatography method with orto-phthalaldehyde (OPA)2-mercaptoethanol pre-column derivatization. Apparatus used: Varian Pro Star; method applied: fluorescence detection $(\lambda \mathrm{ex}=340 \mathrm{~nm}, \lambda \mathrm{em}=455 \mathrm{~nm})$; column: Pursuit C18 $5 \mu \mathrm{m}, 250 \times 4.6 \mathrm{~mm}$; gradient elution: A: $100 \mathrm{mmol} / \mathrm{l}$ acetate puffer $(\mathrm{pH}=6.95) 925 \mathrm{ml}$, methanol $50 \mathrm{ml}$, tetrahydrofuran $25 \mathrm{ml}$, $\mathrm{B}$ : methanol $975 \mathrm{ml}$, tetrahydrofuran $25 \mathrm{ml}$; flow rate: $0.8 \mathrm{ml} / \mathrm{min}$; gradient program for the analysis: 0-8 min; A component $100 \%$, B component $0 \%$, 8-11: 90-10, 11-16: 75-25, 16-20: 60-40, 20-24: 60-40, 24-27: 40-60, 2732: 0-100, 32-33: 0-100, 33-47: 100-0. Under the conditions employed, there was a fairly clear separation of lysine from the other amino acids, while quantification was not disturbed by any circumstances.

\subsubsection{Determination of HMF}

In order to estimate the amount of Maillard reaction products, high-performance liquid chromatography was used to determine the hydroxy-methyl-furfural (HMF) concentration of the bread. For the measurement of HMF, samples taken from the different types of bread were ground in electric mill to $0.75 \mathrm{~mm}$ sieve size. An amount of $1 \mathrm{~g}$ was taken from each sample, to which we added $9 \mathrm{ml}$ of de-ionized water, and then we had it mixed with a Vortex tube mixer. Following this, with a view to eliminate any interfering substances, $0.5 \mathrm{ml}$ of Carrez I and Carrez II solution is added to the extract, and then centrifuged for 10 minutes at 5,000 rpm. The supernatant was removed and filtered through $0.45 \mu \mathrm{m}$ filtration hoods, and $20 \mu \mathrm{l}$ of the obtained solution was injected into the Varian Pro Star HPLC apparatus. Isocratic method was used to measure HMF, where the mobile phase was a 20:80\% mixture of 5\% methanol-acetic acid, the stationary phase was Pursuit C18 column $(250 \times 45 \mathrm{~mm})$, the rate 
flow was $1 \mathrm{ml} / \mathrm{min}$, and UV detection was performed at a wavelength of 285 nm.

\subsection{Sensory analysis}

Bread samples were subjected to sensory analyses that made use of a questionnaire compiled according to the following criteria:

1. Shape: typical of bread (loaf shape), regular, proportionately convex, not deformed.

2. Crust: typical of the particular type of bread; shiny, smooth or cracked; scattered and/or sliced; not split all the way, not sooty/soiled/burned/ saturated/damaged.

3. Internal content: baked thoroughly; does not separate from the crust; the colour is typical of the flour used; the substance is consistent, flexible, and free of lumps; not lardy, sticky, crumbly, or falling apart; does not contain foreign substances and is not damaged by microorganisms.

4. Taste and aroma: aromatic - typical of the particular type of bread, not having strange taste or odour (Codex Alimentarius, 2004).

After cooling, the control bread and the lysine-fortified breads were examined for shape and crust by 20 survey participants. In what followed, we prepared slices of 20-25 g from each sample, containing both crumb and crust parts. Based on these, they compared the breads in terms of internal content, taste, and aroma. Participants could provide a score between 1 and 5 for each of the five properties in the evaluation of which we also made use of weighting factors. The sum of the factors was 4 in each case; thus, the highest possible score for the five property groups altogether was 20. The weighting factors for the individual properties were as follows: shape -0.6 , crust -0.6 , internal content -1.4 , aroma -0.4 , and taste -1.0 .

Sensory analyses began with the inspection of the uncut product. We established the morphological properties and that whether the product volume and mass appear to be proportionate. Crust properties included surface characteristics, colour, crust shine, structure, and substance. Crust thickness must be examined in the sliced product and the consistency of the internal content should also be inspected. Examination of the properties concerning the internal content must be performed on the freshly cut product: it must be established whether the colour is appropriate for the particular product and 
if it is sufficiently consistent throughout the product. The structure of the internal content should be examined by palpation as well on a slice cut out from the central part of the bread. The slice of bread must be at first gently and then more strongly pressed to check for softness and rigidity. Flexibility is examined in the same manner. To establish glutinosity and crumbliness, one must run their fingers over the surface of the slice, and then observe the amount of crumbs created. Glutinosity can be determined by the degree of cohesion.

Aromatic properties were observed as follows: pressure was applied several times on the cut-surface of the halved end-product, and then we had a smell of the volatile substances from the inside. When analysing taste, we must first establish whether it is appropriate for the particular product. We must also find out if any of the following can be observed besides the taste specific of the product: strange, excessively salty/unsalted or sweet taste; too sour/bitter; detection of foreign materials, uncharacteristic of the product, while chewing. At the same time with tasting, we can also feel its substance; therefore, this method helps us determine not only the properties of the internal content but also those of the crust.

\subsection{Statistical evaluation of the data}

We used Microsoft Excel 2010 software package and one-way analysis of variance to perform the statistical evaluation of the data.

\section{Results and discussion}

\subsection{Total protein content of the bread}

To determine the total protein content, the samples taken from the different types of bread were ground in electric mill to $0.75 \mathrm{~mm}$ sieve size, and then an amount of $2 \mathrm{~g}$ was taken from each sample and digested. Digestion and distillation of ammonia were equally repeated three times. We measured the following amounts of protein content: control bread $-8.86 \pm 0.18 \%$, bread made from $0.5 \%$ lysine-enriched flour $-9.20 \pm 0.065 \%$, bread made from $1 \%$ lysineenriched flour $-9.24 \pm 0.038 \%$, bread made from $1.5 \%$ lysine-enriched flour $9.67 \pm 0.037$, and bread made from $2 \%$ lysine-enriched flour $-10.14 \pm 0.023 \%$.

We used one-way variance analysis to demonstrate that the added lysine significantly increases the total protein content of the control bread, but this increase is not such as we would expect from the amount of the added ly- 
sine, what can be explained with the partial decomposition of lysine and the development of the increased amount of Maillard reaction products.

\subsection{Lysine content of the bread}

In order to determine lysine content, bread proteins were hydrolysed with 6 $\mathrm{M} \mathrm{HCl}$ at $110^{\circ} \mathrm{C}$ for a period of 24 hours; then, after appropriate dilution and derivatization, $20 \mu \mathrm{l}$ of the hydrolysate was injected into the high-performance liquid chromatography. We measured the following amounts of lysine content: flour $-0.32 \pm 0.05$, control bread $-0.38 \pm 0.06$, bread made from $0.5 \%$ lysine-enriched wheat flour $-0.48 \pm 0.12$, bread made from $1 \%$ lysine-enriched wheat flour $-0.67 \pm 0.14$, bread made from $1.5 \%$ lysine-enriched wheat flour $0.95 \pm 0.13$, and bread made from $2 \%$ lysine-enriched wheat flour $-1.11 \pm 0.13 \%$. One-way variance analysis showed significant differences.

As a result of the additives' effect, the lysine content of the flour increased from $0.32 \%$ to $0.38 \%$. The added lysine yielded necessarily an increased lysine content in the bread although a certain amount of loss could also be observed. Lysine loss can be explained by the lysine transformation (Maillard reaction) that took place in the bread-crumb, but mostly in the crust during baking. This loss is most striking in the case of the bread made from $2 \%$ lysine-enriched wheat flour, where we measured an amount much less than expected.

\subsection{Amount of the hydroxy-methyl-furfural}

We measured the following amounts of HMF content: control bread $-2.01 \pm 0.05$ $\mathrm{mg} / \mathrm{kg}$, bread made from $0.5 \%$ lysine-enriched wheat flour $-3.25 \pm 0.12 \mathrm{mg} / \mathrm{kg}$, bread made from $1 \%$ lysine-enriched wheat flour $-4.82 \pm 0.07 \mathrm{mg} / \mathrm{kg}$, bread made from $1.5 \%$ lysine-enriched wheat flour $-5.30 \pm 0.15 \mathrm{mg} / \mathrm{kg}$, and bread made from $2 \%$ lysine-enriched wheat flour $-48.02 \pm 0.22 \mathrm{mg} / \mathrm{kg}$. Although the one-way variance analysis of the data showed significant differences, meaning that the added lysine resulted in an increased content of hydroxy-methylfurfural in the bread, a considerable amount was measured only in the case of the $2 \%$ lysine-enriched wheat flour.

\subsection{Sensory analysis results}

Analysis results are included in Table 1.

Regarding shape, we hardly found any difference between control bread and breads made from $0.5-1.5 \%$ lysine-enriched wheat flour, as the respective scores ranged between 4.0 and 5.0. It came as a surprise that the score for 
the bread made from $1.5 \%$ lysine-enriched wheat flour dropped to 3.2 after an additional $0.5 \%$ lysine-enrichment. Similar tendency could be observed in the crust although with much less differences. We found no such correlation in the case of the internal content and, what is more, it appears that in the case of the $2 \%$ lysine-enriched wheat flour lysine supplementation improved internal content as compared to control. Lysine supplementation did not have a significantly adverse impact on the aromatic properties either, but, in fact, breads made from $0.5-1.5 \%$ lysine-enriched wheat flour were assigned a higher score as compared to control and breads made from $2.0 \%$ lysine-enriched wheat flour.

Table 1: Arithmetic mean of the scores assigned to breads

\begin{tabular}{lccccc}
\hline $\begin{array}{l}\text { Bread type } \\
\text { Rated } \\
\text { properties }\end{array}$ & $\begin{array}{l}\text { Control } \\
\text { bread } \begin{array}{l}\text { Bread made } \\
\text { from } 0.5 \% \\
\text { lysine-enriched } \\
\text { wheat flour }\end{array}\end{array}$ & $\begin{array}{l}\text { Bread made } \\
\text { from 1\% } \\
\text { lysine-enriched } \\
\text { wheat flour }\end{array}$ & $\begin{array}{l}\text { Bread made } \\
\text { from 1.5\% } \\
\text { lysine-enriched } \\
\text { wheat flour }\end{array}$ & $\begin{array}{l}\text { Bread made } \\
\text { from 2\% } \\
\text { lysine-enriched } \\
\text { wheat flour }\end{array}$ \\
\hline Shape & 4.2 & 4.6 & 4.0 & 5.0 & 3.2 \\
Crust & 4.2 & 4.4 & 3.8 & 4.6 & 3.7 \\
Crumb & 3.6 & 3.2 & 4.2 & 4.8 & 4.5 \\
Aroma & 3.0 & 4.7 & 4.2 & 4.9 & 3.1 \\
Taste & 4.7 & 4.7 & 4.9 & 5.0 & 1.0 \\
\hline
\end{tabular}

With respect to the examined properties, we obtained the most unexpected results in the case of taste. It appears that the taste of bread remains practically unchanged until reaching a lysine supplementation of $1.5 \%$; moreover, this latter case yielded the highest score. Nevertheless, in the case of the $2 \%$ lysine fortification, the average score of 4.8 plummeted to 1.0 and the bread gained a bitter taste, therefore becoming unpalatable.

We multiplied the scores for bread in Table 1 with the weighting factors, and obtained the following values:

Table 2: Scores for the different types of bread Bread types

\begin{tabular}{lccllc}
\hline $\begin{array}{l}\text { Bread } \\
\text { type }\end{array}$ & $\begin{array}{l}\text { Control } \\
\text { bread }\end{array}$ & $\begin{array}{l}\text { Bread made } \\
\text { from } 0.5 \% \\
\text { wheat flour }\end{array}$ & $\begin{array}{l}\text { Bread made } \\
\text { from 1\% } \\
\text { lysine-enriched } \\
\text { wheat flour }\end{array}$ & $\begin{array}{l}\text { Bread made } \\
\text { from 1.5\% } \\
\text { lysine-enriched } \\
\text { wheat flour }\end{array}$ & $\begin{array}{l}\text { Bread made } \\
\text { from 2\% } \\
\text { lysine-enriched } \\
\text { wheat flour }\end{array}$ \\
\hline $\begin{array}{l}\text { Achieved } \\
\text { score }\end{array}$ & 15.98 & 16.46 & 17.14 & 19.44 & 12.68 \\
\hline
\end{tabular}


Multiplying the scores with the weighting factors led to similar conclusions. As an effect of $5 \%$ lysine supplementation, the 15.98 score of control bread increased to 16.46 , after $1 \%$ lysine supplementation, it went up to 17.14, after $1.5 \%$ lysine supplementation to 19.44 , while after $2 \%$ lysine supplementation, due to the extremely low score given for taste, it dropped to 12.68. Data in Table 2 suggest that the highest score was achieved by the bread made from $1.5 \%$ lysine-enriched flour, which leads us to the conclusion that this type of bread disposes of the most favourable sensory properties. Bread made from $2 \%$ lysine-enriched flour received the lowest score due to its strong bitter taste; its crust had a much darker colour in comparison with other breads and its aroma score was also very low: 3.1. According to sensory analysis results, 1.5\% lysine supplementation enhances the palatability traits of the bread, namely its taste and colour, but it also affects the development of its internal content in a positive way.

\section{Conclusions}

Performing the sensory analysis, we concluded that the enrichment of wheat flour with $0.5-1.5 \%$ lysine either improved sensory properties or did not change them at all as compared to control bread, but breads cannot be enriched with a proportion exceeding $1.5 \%$ since that would increase the concentration of the Maillard reaction products, which has a negative influence on the taste factor. Besides taste, bread-crust gains a much darker shade, which is undesirable for customers. The hydroxy-methyl-furfural content of the bread made from $2 \%$ lysine-enriched flour is much higher than that of the breads with a lower amount of lysine supplementation - therefore, we put down the appearance of the strong bitter taste to this fact.

Considering our future research work, the next step is to examine the amount utilized from the added lysine, have a look into the changes in the lysine/arginine ratio of the obtained breads, and study whether lysine produces therapeutic effects in such concentration. Descriptions found in literature did not include studies on breads made from flour with an added lysine content higher than $0.6 \%$, wherefore our results could not be compared with literature data. Lysine supplementation of $1.5 \%$ or less enhances the palatability traits of bread and yields a functional food with a balanced amino acid composition and higher biological value, while it might also produce therapeutic effects. 


\section{Acknowledgements}

The authors express their grateful thanks to the Scientific Research Department of the Sapientia Foundation for the financial support offered under Contract No $12 / 4 / 28.04 .215$.

\section{References}

[1] A. A. Anton, K. A. Ross, O. M. Lukow, R. G. Fulcher, S. D. Arntfield, Influence of added bean flour (Phaseolus vulgaris L.) on some physical and nutritional properties of wheat flour tortillas. Food Chemistry, 109. (2008) 33-41.

[2] R. Civitelli, D. T. Villareal, D. Agneusdei, Dietary L-lysine and calcium metabolism in humans. Nutrition, 8. (1992) 400-404.

[3] J. Csapó, Zs. Csapóné Kiss, L. Babinszky, Z. Győri, L. Simonné Sarkadi, J. Schmidt, Élelmiszer- és takarmányfehérjék minösitése [Qualification of proteins of food and foodstuff]. Mezőgazda Kiadó, Budapest, 2006.

[4] J. Csapó J., Zs. Csapóné Kiss, Élelmiszerkémia [Food chemistry]. Mezőgazda Kiadó, Budapest, 2004.

[5] J. Csapó, Zs. Csapóné Kiss., Biokémia - állattenyésztőknek [Biochemistry for animal breeders]. Mezőgazda Kiadó, Budapest, 2007.

[6] J. Csapó, Zs. Csapóné Kiss, Cs. Albert, Sz. Salamon, Élelmiszerfehérjék minősitése [Qualification of food proteins]. Scientia Kiadó, Kolozsvár, 2007.

[7] M. E. A. El-Megeed, D. C. Sands, Methods and compositions for improving the nutritive value of foods. United States Patent 4897350. January 30. 1990.

[8] J. Figueron, G. Acero, M. Vasco, A. L. Guzman, M. Flores, Nutritional quality of nistamal tortillas fortified with vitamins and soy proteins. International Journal of Food Science and Nutrition, 54. (2003) 189200.

[9] Karcz S., Food and nutritional bulletin. Boston, 2004. 
[10] D. D. Kitts, C. Hu, Biological and chemical assessment of antioxidant activity of sugar-lysine model Maillard reaction products. Annals of the New York Academy of Sciences, 1043. (2005) 501-512.

[11] M. Lindenmeier, T. Hofmann, Influence of baking conditions and precursor supplementation on the amounts of the antioxidant pronyl-Llysine in bakery products. Journal of Agricultural and Food Chemistry, 52. (2004) 350-354.

[12] J. Mauron, P. A. Finot, F. Mottu, Process for fortifying foodstuffs with pro-lysines. United States Patent 3993 795. November 23. 1976.

[13] A. Mora-Aviles, B. Lemus-Flores, R. Miranda-Lopez, D. HernandezLopez, J. L. Pons-Hernandez, J. A. Acosta-Gallegos, Effects of common bean enrichment on nutritional quality of tortillas produced from nixtamalized regular and quality protein maize flours. Journal of the Science of Food and Agriculture, 87. (2007) 880-886.

[14] H. A. Muhammad, R. Taha, E. Khalil, A. Inteaz, A. Ali, M. Nather, N. Mohammad, Effects of barley flour and barley protein isolate on chemical, functional, nutritional and biological properties of Pita bread. Food Hydrocolloids, 26. (2012) 135-143.

[15] L. Pauling, Case report: Lysine/ascorbate-related amelioration of angina pectoris. Journal of Orthomolecular Medicine, 6. (1991) 144146.

[16] R. E. C. Wildman, Nutraceuticals and functional foods. Taylor \& Francis Group, Boca Raton, London, New York. 2007.

[17] M. Rath, Aszkorbátot és lizint tartalmazó szinergetikus készítmények extracelluláris mátrixdegeneráció ellen. P 0100188. 2001.01.16.

[18] H. Tajammal, A. Shaid, A. K. Mushtaq, S. S. Nevin, Lysine fortification of wheat flour improves selected indices of the nutritional status of predominantly cereal-eating families in Pakistan. Food Nutritional Bulletin, 25, 2. (2004) 114-122.

[19] S. T. Titcomb, A. A. Juers, Composition for preparing a high complete protein wheat bread. United States Patent 3995 065. November 30, 1976. 
[20] S. K. Tyagi, M. R. Manikantan, H. S. Oberoi, G. Kaur, Effect of mustard flour incorporation on nutritional, textural and organoleptic characteristics of biscuits. Journal of Food Engineering, 80. (2007) 10431050 .

[21] Z. Wenhua, Z. Fengying, Z. Ding, A. Yunqing, L. Ying, H. Yuna, G. Keyou, S. S. Nevin, Lysine-fortified wheat flour improves the nutritional and immunological status of wheat-eating families in Northern China. Food and Nutrition Bulletin, 25, 2. (2004) 123-129. 